\title{
Prevalence of Tertiary Level Students' Critical Thinking Skills in Speaking
}

\author{
Agung Ginanjar Anjaniputra \\ Department of English Education, Universitas Negeri Semarang, Indonesia
}

anjaniputragi@mai.unnes.ac.id

First draft received: 10 Jul 2019 Date Accepted: 15 Jan 2020 Final proof received: 17 Jul 2020

\begin{tabular}{l} 
Abstract \\
Critical thinking is deemed vital to students' success of learning. Not only does it help in processing \\
information received through written and oral communication, but also it enhances the quality of language \\
which is produced logically and reasonably. Critically thinking of what to say has been deemed intricate \\
and more demanding by most students. Thus, this study is intended to investigate critical thinking of \\
students at tertiary level, particularly critical thinking aspects demonstrated in speaking. To address this \\
issue, this study deploys a case study qualitative design to gain in-depth, thorough, comprehensive \\
understanding. Involving the second year university students, this study results in findings that some \\
aspects of critical thinking are demonstrated by the students in their speaking performance, encompassing \\
relevance, clarity, consistency, accuracy and fairness, and that trends of how these aspects of critical \\
thinking occurs, entailing deductive and inductive reasoning, cause and effect, comparison, planning as \\
well as hypothesizing, are interpreted and discussed. Therefore, critical thinking is necessary and this \\
needs improvement if students' success in the new world era is to be attained. \\
Keywords: critical thinking; speaking; students; tertiary level \\
\hline \hline \\
To cite this paper (in APA style): \\
Anjaniputra, A. G. (2020). Prevalence of tertiary level students' critical thinking skills in speaking. \\
International Journal of Education, 13(1), 18-25. doi: 10.17509 /ije.v13i1.18196 \\
\hline
\end{tabular}

\section{INTRODUCTION}

Critical thinking constitutes one prerequisite skill in higher education (McMillan, 1987; Pike, 1996; Bers, 2005; Miekley, 2014). It is required to promote students' success in this globalized world (Schafersman, 1991; Marin \& Halpern, 2010; Miekley, 2014; Junining, 2016). It is also associated with the problem-solving ability. Yet, to critically and communicatively convey ideas in English is sometimes burdensome for EFL students in higher education (Masduqi, 2011). It is a glitch since, according to Gustine (2014 cited in Apsari, 2016) critical thinking is said to be essential for higher education.

Notwithstanding the primacy of critical thinking in higher education, students in tertiary level are loath to use and even develop their critical thinking skills, particularly when they are producing spoken language. They seem to utter words, phrases, clauses or texts which is deemed easier as long as they can speak fluently regardless of the content. Besides, speaking in foreign languages is more difficult than speaking in the mother tongue, resulting in a large burden on students. In this regard, Masduqi (2011) affirms that lack of critical thinking and difficulties to convey ideas communicatively and critically may result from teacher-centered learning in primary and secondary schools. For that reason, it becomes crucial to explore not only critical thinking among college EFL students, but also that in speaking performances.

In Indonesia, critical thinking is to be implemented in the curriculum as it is embodied in the latest Curriculum 2013 (Ariyana, Pudjiastuti, Bestary, \& Zamroni, 2018). This denotes the urgency of critical thinking among the youth. Having students used to critical thinking skills before they advance to higher education is a strategy to prepare them to deal with the globalization era. In addition, by teaching critical thinking skills, the way of knowing is not only about getting knowledge, but also some procedural ways to question what is known through reasoning or assertions, so what is true is definite and certain. Hence, the students in today's higher education or tertiary level are at least exposed to the teaching of critical thinking and are supposed to have a firm foundation of it.

In tertiary level, students learning to master a second or a foreign language need various language skills and even the integration of two of the language skills. Before a person speaks, the person must have been introduced and listen to the utterances. To promote students' thinking when they are performing such skills, critical thinking is required. In this regard, one language that is learnt to be able to speak bursts 
one's creative and critical thinking skills (Busch cited in Bowman, 2010). Furthermore, critical thinking skills can help students to optimize their language competence in order to perceive and produce text effectively as well as reflectively. Hence, critical thinking in speaking is vital to ensure the provision of ideas is acceptable, understandable, and sensible.

Critical thinking has its own standards so that one can be considered critical in their thinking. This is in line with Bassham, Irwin, Nardone, \& Wallace, (2014, p.1) that it is "disciplined thinking governed by clear intellectual standards". It is further argued that these standards encompass clarity, precision, accuracy, relevance, consistency, logical correctness, completeness, and fairness. The standards to some extent bear a resemblance to "intellectual standards" proposed by Paul (2005). These are to be presented in the following paragraphs in detail.

Clarity means that understanding clearly what others are saying is vital before effectively evaluating the argument or claim. It cannot be taken for granted since by carefully making others point clear, miscommunications and disappointments can be precluded. However, it is not easy to clearly comprehend others' utterances or ideas because unclarity of ideas can result from laziness, carelessness, a lack of skill or even a misguided effort to be considered profound (Bassham et al., 2014). Critical thinkers make every attempt to pursue clarity at its pinnacle through self-understanding of thought (Bassham et al., 2014).

Precision is another standard of critical thinkers. It has something to do with the primacy of precision by careful and highly trained observation so that all can be precisely noticed. Precise answers must be available for precise questions. This can solve many everyday problems and issues by dealing with confusions and uncertainties. To think precisely, one can ask something to its edge of certainty, which generate questions such as what exactly is the problem? What exactly are the alternatives? What are the advantages and disadvantages? (Bassham et al., 2014).

In regard to accuracy, according to Bassham et al. (Bassham et al., 2014) a good decision can solely be generated if the information is accurate, not the false one. This indicates that valuing the truth is not enough, what is more important is the commitment to accurate, timely information. Decisions made should always be as informed as possible if the accuracy standard is supposed to be attained. Hence, it is vital to be well-informed about and strive harder for accurate information before coming into a conclusion because what you earn is what you possess. Ideally, the accurate information results in the informed decision, and vice versa, the inaccurate information misleads the decision.

Relevance deals with "logical relevance to the strength of one's arguments" (Bassham et al., 2014, p.4). An argument can only be strengthened, so that others deem it true, by providing relevant ideas and information. If not, this will lessen the argument and in turn make others feel unnecessary to uphold the argument. No jokes are necessary in presenting arguments, unless this is logically relevant to the argument. The ability to keep your argument relevant to what is being said is one proof that one is a critical thinker.

In addition, critical thinkers have to be consistent in a way that is consequent to what they say or believe. To see whether or not someone is consistent can be recognized by two kinds of inconsistency, logical and practical inconsistency (Bassham et al., 2014). The first one is logical inconsistency, dealing with arguing and holding inconsistent things about a certain matter. So, to be critical thinkers, it is better to be logically consistent with what is believed to be true. In other words, persistence in believing what is true about something is the utmost importance. The second one is practical inconsistency, having to do with a gap between what is said and what is done. This implies that consistency between saying and doing is of critical thinking, allowing for full awareness of using words for deeds.

Critical thinkers are also to bear in mind that conclusions are drawn from the held beliefs so that the conclusions are well-founded, which constitutes the so-called logical correctness standard. Reasons given must be correct, which are based upon accurate and well-supported beliefs. However, illogical reasons are more common among human, as Bassham et al (2014) mention, conveyed by Russel in his classic essay, that the pious nuns could draw correct conclusions that "God sees everything", which they believe "God sees Bathroom walls", yet they failed to provide logical correctness following previous reasons to a premise that "God sees through bathrobes" (p.6). Logically, walls which is thick and robust can be seen through, and bathrobes definitely can be too, but they illogically could not support such a reason.

To follow previous standards, completeness comprises deep and complete thinking. It is asserted that "thinking is better when it is deep rather than shallow, thorough rather than superficial" (Bassham et al., 2014). Eventhough sometimes in certain contexts it is improbable to discuss an issue in depth, people prefer completely thorough explanations in many contexts such as criminal investigations, jury deliberations, news stories, driving directions and medical diagnoses. Therefore, critical thinkers require completeness in thinking.

With all the standards described beforehand, another crucial aspect is fairness. It means being open-minded, impartial, and free of distorting biases and preconceptions. It may be hard to achieved since the way people think is highly influenced by how the culture and previous prior knowledge shape the mind. Besides, resistance to unfamiliar ideas, prejudgement about issues, outsider stereotyping, truth identification with own self-interest are examples of why fairness in 
thinking is difficult. Despite such conditions, fairness is of importance in critical thinking. Hence, the inclusion of all the standards can result in what is meant to be critical thinking.

Some studies on critical thinking were conducted in the EFL context in relation to language skills. They were concerned with reading skills, writing skills, listening skills as well as integrating critical thinking into these language skills. An investigation of critical thinking in English language teaching in general was conducted (Masduqi, 2011; Tosuncuoglu (2018); Vdovina; 2013), incorporating critical thinking in the classroom. A rather similar study by Junining (2016) explored how to develop critical thinking among students through oral interpretation class. Regarding reading skills, aspects of critical thinking skills are explored with an emphasis on those of students in High School (Putri, 2014) and in college (Husna, 2019; Zheng, 2014). In addition, students' critical thinking skills are examined to focus on the enhancement of the skills (Buranapatana, 2006; Changwong, Sukkamart, \& Sisan, 2018; Ralston \& Bays, 2015). Moreover, the portrayal of critical thinking skills in EFL academic writing produced by the Japanese in University level was done due to an issue of the students' lack of critical thinking (McKinley, 2013). However, studies on aspects of critical thinking demonstrated in speaking performance are still scarcely conducted in any levels of education; primary, secondary and tertiary levels. For this reason, it is deemed essential to investigate the aspects of critical thinking in higher education, in this sense university students.

As speaking performances are emphasized in this study due to students' difficulties and inadequate skills, it is worth noting that the activity for teaching speaking is different from the activity for teaching writing because the main focus of the two skills is not the same. The main focus of teaching speaking is intended to enable students to produce the language orally. As a result, the activities should be designed to give students any speaking opportunities and obstacles that impede students' potential in achieving the objectives should be minimized. In order to maximize speaking opportunities and increase the chances that students will experience autonomous language use, Brown (2001) suggests seven principles for designing speaking activities taking into account student needs, motivating techniques, authenticity, feedback, connection between listening and speaking, students' opportunity, and speaking strategies.

Given the considerations that critical thinking skills are required and likely to provide students with a multitude of advantages, especially in higher education as suggested by some experts, and that speaking are the most prevalent skill in this new digital era, critical thinking aspects investigated in this study deals with those demonstrated particularly in tertiary level students' speaking performance. This is intended to explore critical thinking in terms of the aspects or standards demonstrated by students and the extent to which they are capable of thinking critically in speaking performance. With these purposes, students' oral performance is required to portray the demonstrated standards and the extent of their critical thinking.

\section{METHOD}

In accordance with the research problem and the aim of this study to investigate demonstrated aspects of critical thinking by tertiary level students, a case study design is deployed. This qualitative design is utilized by virtue of the necessity to yield in-depth, thorough understanding of the problem. This denotes that a case study is concerned with merely one or more subject of occurrence examined with a highly centralized focus. In this sense, the use of a case study design is deemed essential since this study puts emphasis on one case which is students' critical thinking in speaking. Besides, critical thinking in speaking becomes the only subject to be investigated in a way that it is to result in comprehensibly unified findings.

Out of the populations, five second year college students were chosen purposively as the sample. They were selected as they were considered the high achievers in the classroom. These students were to perform their speaking skills whose result was transcribed and analyzed to investigate the manifestation of critical thinking aspects. In the meantime, the selection of them was intended to reveal more information about the depiction of critical thinking of students in that grade.

In this study, the technique for collecting the data was mainly administered through recording and transcribing students' oral texts. A topic was given in a speaking course, requiring the students to inquire about English learning problems by asking two friends. As they got the information on the problems, they had to think through all possible solutions to deal with the problems before they spoke. So, the students conveyed the problems experienced by their friends and the solutions to the problems. which was recorded by the researcher. The recording was then transcribed to result in analyzable documents. Such documents are expected to be a medium for investigating demonstrated aspects of critical thinking in speaking.

The data collection is based upon the recommendations for assessing critical thinking proposed by Lai (2011), encompassing the appropriateness of employing open-ended measures, authentic problem contexts and performances, qualitybased evaluation, as well as the reinforcement of student reasoning. Unlike closed-ended questionnaires or Likert scales, an open-ended measure is deployed in this study since after interviewing two classmates the students are asked how to solve their friends' English learning problems. So the students freely express ideas and solutions for their friends' problems. In addition, this is also authentic in terms of contexts and performance in a way that difficulties of learning are undergone in reality 
by their friends. Moreover, what is sought in the students' texts is the quality of their arguments regardless of being right or wrong. This is also shown that the activity to provide solutions for learning problems stimulates student reasoning.

As for the data analysis, the critical thinking aspects demonstrated in speaking performance are emphasized as stated in the research question section. In general, the steps of the analysis include coding, categorization, and interpretation. Coding is carried out to identify aspects of critical thinking in the data after the transcribing process. In addition, categorization is intended to classify the coded utterances of students in terms of critical thinking aspects. This is done to ease the identification and classification of the mood structure employed in the texts. This also aims to help in interpreting the data. In this sense, interpretation is conducted to give meaning and insight of what the critical thinking aspects suggest as it is uttered by the students in their performance, which is in turn associated with previous research and theories vis-a-vis critical thinking.

\section{RESULTS AND DISCUSSION \\ Aspects of critical thinking students demonstrate in speaking performance}

Aspects of critical thinking conveyed in this study is in accordance with eight standards proposed by Bassham et al. (2014). The standards entail clarity, precision, accuracy, relevance, consistency, logical correctness, completeness, and fairness. These standards are what is required to be a critical thinker and are widely used (see Austin, 2012; Bassham et al., 2014; Paul \& Elder, 2005; Paul \& Elder, 2013; Ralston \& Bays, 2015; Uribe-Enciso, Uribe-Enciso, \& del Pilar Vargas-Daza, 2017). Each of the standards is going to be explained sequentially in relation to its prevalence in the students' oral texts as well as be discussed as opposed to or in line with previous corresponding theories in the following paragraphs.

Table 1. Critical thinking standards in the texts

\begin{tabular}{|c|c|c|c|c|c|}
\hline \multirow{2}{*}{$\begin{array}{l}\text { Critical } \\
\text { thinking } \\
\text { aspects }\end{array}$} & \multicolumn{5}{|c|}{ Students' oral texts } \\
\hline & $\begin{array}{c}\text { Text } \\
1\end{array}$ & $\begin{array}{c}\text { Text } \\
2\end{array}$ & $\begin{array}{c}\text { Text } \\
3\end{array}$ & $\begin{array}{c}\text { Text } \\
4\end{array}$ & $\begin{array}{c}\text { Text } \\
5\end{array}$ \\
\hline Clarity & $\sqrt{ }$ & $\sqrt{ }$ & $\sqrt{ }$ & $\sqrt{ }$ & $\sqrt{ }$ \\
\hline Precision & - & - & - & - & - \\
\hline Accuracy & $\sqrt{ }$ & $\sqrt{ }$ & $\sqrt{ }$ & $\sqrt{ }$ & $\sqrt{ }$ \\
\hline Relevance & $\sqrt{ }$ & - & - & $\sqrt{ }$ & $\sqrt{ }$ \\
\hline Consistency & $\sqrt{ }$ & $\sqrt{ }$ & $\sqrt{ }$ & $\sqrt{ }$ & $\sqrt{ }$ \\
\hline $\begin{array}{l}\text { Logical } \\
\text { correctness }\end{array}$ & - & - & - & - & - \\
\hline Completeness & - & - & - & - & - \\
\hline Fairness & - & $\sqrt{ }$ & $\sqrt{ }$ & $\sqrt{ }$ & $\sqrt{ }$ \\
\hline
\end{tabular}

In the activity before students made their own oral texts, they were assigned to interview their partners vis-à-vis their difficulties in learning English.
As they finished the interview, they had to think about the solutions to their friends' problem. It indicates that the activity requires them to have a sense of clarity before determining best possible solutions to the learning problems. This is in line with Bassham et al. (2014) that clarity means that understanding clearly what others are saying is vital before effectively evaluating the argument or claim. In other words, once their partner conveys their problems in learning English, those who have a sense of clarity will be capable of thinking through the problems so as to take into account any available answers. The interview carried out by students is originally to elicit ideas. Eliciting ideas constitutes the stage that can be implemented to teach critical thinking (Masduqi, 2011). Understanding of the problems faced by their friends is conveyed as one of the students attempted to synthesize the problems of her friends.

So, guys, we have four problems from them, one, how not to get nervous; two, how not to be confused about grammar; three, how to be confident; four, how to pronounce words correctly. \#S3

Of all students' text analyzed, the solutions, such as believing in yourself, keeping up the learning, practicing in front of mirrors, listening to music, being relaxed and confident, reading everyday, etc., show decent clarity in a way that misunderstanding or miscommunication hardly appears. The texts can address all the problems clearly without resulting in ambiguity, despite some other aspects of critical thinking, which are discussed later in this section, may not be nicely put. Among others, the solutions provided encompass believing in yourself to cope with lack of confidence in speaking, listening to songs to improve vocabulary mastery, singing a song to improve pronunciation, and so on. Paul (2005) asserts that once an individual can provide examples and elaboration, the clarity standard of thinking critically is fulfilled. Therefore, the ability of students to make use of this aspect is deemed sufficient as seen from the logic of their thoughts in the provision of ideas, because reversely a lack of skill brings about unclarity of ideas (Bassham et al., 2014).

In addition, precision is one of the aspects neglected by the students in their oral texts as they only ask superficial questions to their partner about their learning problem. Instead, to think precisely, one can ask something to its edge of certainty, such as what exactly is the problem? What exactly are the alternatives? What are the advantages and disadvantages? (Bassham et al., 2014). In a similar sense, Vujic \& Jerkovic (2014) assert that people thinking critically can raise vital questions, and formulate the questions used to gather relevant information to come up with well-informed conclusions or decisions to solve complex problems. It can be seen that the students in their performance do not talk about further problem examination of their partners'. They merely elicit the problem then logically provide 
possible solutions or answers. If they had asked something to its edge, they should have explained it in their texts and the solutions would not have been directly appointed to the problem. For example, one of them said, "She has a difficulty to memorize the vocabulary. And for this problem I have four solutions to solve this problem" (\#S5). The student did not ask why, when, how can, and to what extent his/her friend is difficult to memorize words. Such questions are vital to generate precision.

The detailed information on the problem can definitely determine the provision of solution. Nonetheless, superficial questions delivered by the students lead to superficially good answers in their oral texts. More precise answers must have been available. In this sense, Hughes (2014) suggests there is a need for students to foster critical questioning so as to become effective critical thinkers.

By looking at the solutions provided by the students in their oral texts, it is very likely that the arguments are accurate in addressing the problems. The way students decided to come to the given solution is based upon the timely accurate information from their partner. If the information obtained is inaccurate, the decision about the solutions will be misleading. The decisions are all sufficiently wellinformed as no false or ambiguous solutions are found. For example, in attending to a grammatical problem in learning English, the occurrence of the inaccuracy aspect could have resulted in a solution such as learning various verb forms. This is misleading as grammar is not only about verbs, and learning solely verbs may generate other grammatical problems such as sentence structures, subject-verb agreement, passive forms, etc.. Yet, learning the tenses and their use is proposed as in "...should learn from the basis especially tenses" (\#S2). Therefore, accuracy is essential since according to Bassham et al. (2014) a good decision can solely be generated if the information is accurate, not the false one. this is in line with Bailin et al. (1999, cited in Lai, 2011) that critical thinking can be realized when the standard of accuracy is met.

Relevance deals with "logical relevance to the strength of one's arguments" (Bassham et al., 2014, p.4). It is reflected in one student's arguments when asserting the primacy of talking before the mirror to gain confidence in speaking. The student illustrates how important it is by describing her experience: "Make the mirror your best friend.... I'm pretending like I'm the famous girl. So, it works" (\#S1). This indicates that the student attempts to make the argument relevant to the problem, which is to increase confidence in speaking. Besides, the presence of her experience about talking before mirrors seems to strengthen the argument in a way that at least the strategy to gain confidence in speaking is to some extent successful and possibly yields the same result as it is to the speaker. The presence of such arguments manifests the relevance standard since this standard is said to be concerned with a strong relationship between arguments and matters being discussed (Paul, 2005).

Since this analysis is based upon the speaking performance of the students, it will merely focus on how the argument is consistent. According to Bassham et al. (2014), the consistence can be seen from the inconsistency entailing logical and practical inconsistency. In this regard, one logical inconsistency is obvious in one of the students' oral texts. The logical inconsistency is indicated when the speaker proposes a solution to believe in our self. Nevertheless, instead of supporting the arguments with convincing facts or evidence, the speaker says that "maybe it sounds hard and not all of people can do it, but this step is really important" (\#S1). The argument about believing in yourself may have been stronger and convincing to make the person confidence in speaking. The inconsistency generates a weak spot of the argument and is likely to create doubts in the listeners. However, the student can provide practical consistency of what is said and done in relation to talking to the mirror, which is based upon what she has usually applied.

Logical correctness has to do with conclusions which are drawn from the held beliefs and are wellfounded. In other words, generalizations created in our mind have to be based on careful considerations of all information and evidence available. Missing one fact can bear illogical arguments. In regard to this, the students failed to fulfil the provision of logical correctness as the arguments are presented without the explanation how they come up with the solution. Moreover, they did not refer to or cite well-supported beliefs. As a result, listeners in this sense cannot see how logical it is to use the solutions given. Their arguments must be firm and acceptable if this standard is realized in the texts.

Regarding the standard of completeness, a critical thinker requires deep and complete thinking. However, most of the arguments presented in the texts regarding problems in learning English merely cover the surface of the actual necessity to overcome the problems. For example, when the students express the solutions, the students just mention the ideas one by one without being elaborated. They hardly have completeness in thinking because they discuss the problems and the solution superficially. One of the solutions offered by students is: "Try calming exercises, close your eyes and slow down your breathing rate." (\#S3)

The excerpt indicates that the students seem not to have the ability to elaborate ideas. According to Paul \& Elder (2005), deep thinking entails complexities, multiple interrelationships and many variables in the ideas. The students should have considered all variables included in the solution so that completeness can be attained. This is to some extent associated with their ability to get precise information as previously discussed. It seems that the precise standard or the ability to get certainty results in lack in completeness in thinking. Thus, to pursue the ability to 
think thoroughly, shallow and superficial thoughts and criticism must be avoided (Austin, 2012).

Of all arguments presented by the students to overcome problems in learning English, they presented all the possibility including unfamiliar ideas such as uttering spells. This to some extent denotes the realization of the fairness standard in critical thinking where a critical thinker is open-minded, impartial, and free of distorting biases and preconceptions. In the case of uttering spells to deal with lack of confidence in speaking, it is done to motivate themselves. Although it is not the real spell related to magic, it is interesting to look at how the student choose the word "spells", which is considered taboo and opposed to the held belief of the community. This denotes a disposition of critical thinking, namely fair-mindedness (Lai, 2011), where the individual is capable of producing impartial and just judgements regardless of his/her beliefs.

In a nutshell, the students' oral texts have certain standards of critical thinking encompassing clarity, accuracy, relevance, some extent of consistency as well as fairness. In the meantime, a number of standards entailing precision, logical correctness, and completeness are absent. These rarely found standards emphasize the ability to elicit exactly what is the case so as to attain thorough understanding and logically well-developed reasons for the given arguments. Their absence may be caused by students' lack of enthusiasm. Concerning this, Buskist and Irons (2008, cited in Rezaei, Derakhshan, \& Bagherkazemi, 2011) specify reasons underpinning their reluctance to think critically, two of which are concerned with students being told what to do and when to do and with students being wont to learn information by heart without thinking about it. Thus, teachers should promote the provision of learning activities that engage students in meaningful discussions on appealing topics.

\section{The extent of students' critical thinking in speaking performance}

To assess the extent of students' critical thinking, several dispositions of arguments identical to thinking critically are discussed (Hughes \& Lavery, 2008; Lau, 2011; Bassham et al., 2014; Kelley, 2014). Their critical thinking is described one by one per text based upon the speakers' arguments expressed in their own texts. These will cover logical thinking and reasoning including skills such as deductive and inductive reasoning, comparison, cause/effect, forecasting, planning, and hypothesizing, some of which are absent in the students' texts. By doing so, it is expected that the extent to which students think critically can be apparent.

In Text 1, one apparent indication of critical thinking is deductive reasoning when the student argues about using phones for improving speaking in English. The student comes up with this conclusion by considering the ideas of always listening to English in this digital era as the information can rapidly be gotten. She contends that the information is all in our hand where we can learn English through a multitude of social media. In addition, as the use of phones brings about drawbacks effect among its users, she deductively concludes that phones are supposed to be used for learning improvement. In deductive reasoning, the presence of premises ensure that the conclusion is true (Hughes \& Lavery, 2008). In other words, the argument that phones must be used for enhancing speaking is justified by rapid information change and its availability in our hand.

In addition, it is found in Text 2 that cause and effect are presented by highlighting the importance of partner for learning English. The student is able to exemplify the effect of learning English without partners. Moreover, the effect of learning with a partner is also conveyed by the speaker. This shows certain skills of critical thinking, where the speaker provides readers with the possibility that may occur when learning with or without partners. This occurrence, to follow Bassham et al. (2014), refers to a prediction associated with happenings in the future with a following reason. Judgements vis-à-vis probability are of logic, albeit its common association with determining whether or not something is true (Kelley, 2014). As a result, with the possibility, readers can make themselves clear of what they prefer. Such arguments can certainly be left out by an uncritical thinker.

Another salient element of critical thinking is classification (Kelley, 2014), as shown in Text 3, yet the student or speaker cannot completely organize the ideas. The speaker attempts to categorize problems encountered by her friends, but the categorization is simply too superficial. For instance, she classifies the problems into four things including nervousness, confidence, grammar, and mispronunciation. If the speaker can carefully think about the origins of confidence and nervousness, one general problem can be generated. In this sense, it is very likely that the speaker lacks one previously explained standard of critical thinking, namely precision, which can be probed by a question "could you be more exact?" (Paul, 2005).

Notwithstanding arguing some ideas superficially, it needs to be noted that the student in Text 4 shows certain levels of inductive reasoning. This is used when the student argues about the importance of getting rid of nervousness in speaking. The inductive reasoning begins with the premise that alleviating nervousness is required in speaking as the students find it difficult. Another premise is that usually the cause of our nervousness when we are talking is thinking too much about people's opinion. Finally, it is inductively presented that nervousness can disappear by trying to be the one who doesn't care about others' perception. This denotes one inductively strong argument since the conclusion of ignoring others' 
opinion is derived from strong supports of the premises (see Lau, 2011).

In the last text, which is Text 5 , instead of finding indications of critical thinking, thinking fallacy is found. It is manifested in the argument that proposes reading to tackle the difficulty in memorizing the vocabulary. It is first affirmed that by reading, ones can be exposed to various numbers of words. Following the previous argument, the speaker expresses that reading can increase vocabularies, as the speaker cites one source. Nonetheless, it is clear that the idea that reading can increase vocabulary cannot explain how reading allows for memorizing vocabularies since the difficulty in memorizing vocabulary is associated with the forgotten words that should have been known. In the meantime, increasing vocabulary is extending the range of vocabulary mastery, having nothing to do with ease memorization of certain words. This denotes an inductive fallacy resulting from weak premises in generating conclusions, also known as "hasty generalization" (Wood, 2002; Moore \& Parker, 2009).

The findings in this study denote an emerging capacity of the students to think critically in EFL speaking. However, some standards are not realized in how they speak. This indicates a limit in critical thinking skills performed and possessed by the students. The findings to some extent bear a resemblance to the studies in Turkey and Thailand that the development of students' critical thinking skills was limited (Bilgin \& Eldeleklioğlu, 2007; Rujivanarom, 2016, cited in Changwong, et al., 2018). Therefore, the teachers should teach critical thinking to students not only in reading and writing but also in listening and speaking in particular. This should be done earlier so as students continue their study to higher education, they will have been accustomed to activating critical thinking skills, which promotes the optimal development of the skills for their success.

\section{CONCLUSION}

Although the students were all in tertiary level of education, not all standards of critical thinking were met. Among others, three standards encompassing precision, logical correctness, and completeness are lacking in their speaking performance. In addition, in presenting the arguments, the students hardly used analogies which might have helped them strengthen their arguments. Instead, inductive and deductive reasoning as well as cause and effect are the most prevalent characteristics among their arguments. Thus, it is vital for teachers to teach the students critical thinking skills, which in turn can bring them success in this new digital era. It is also suggested critical thinking skills be taught earlier so as to prepare students as they continue the study to the tertiary level.

\section{REFERENCES}

Apsari, N. P. A. N. (2016). Teacher's way to foster critical thinking in the classroom (A Case Study of a Senior High School in Bandung). UPI Journal of English and Education, 4(1), 51-72.

Ariyana, Y., Pudjiastuti, A., Bestary, R., \& Zamroni. (2018). Buku pegangan pembelajaran berorientasi pada keterampilan berpikir tingkat tinggi. Jakarta: Direktorat Jenderal Guru dan Tenaga Kependidikan, Kementerian Pendidikan dan Kebudayaan.

Austin, M. W. (2012, June 11). Standards of critical thinking: Thinking towards truth. Retrieved from https://www.psychologytoday.com/us/blog/ethics -everyone/201206/standards-critical-thinking.

Bassham, G., Irwin, W., Nardone, H., \& Wallace, Ja. M. (2014). Critical thinking: $A$ student's introduction (4th ed.). The McGraw Hill.

Bers, T. (2005). Assessing critical thinking in community college. New Directions for Community Colleges, (130), 15-25. https://doi.org/10.1002/cc.192

Bilgin, A., \& Eldeleklioğlu, J. (2007). An investigation into the critical thinking skills of university students. H. U. Journal of Education, 33, 55-67.

Bowman, K. D. (2010). Critically speaking. International Educator's 2010 Language Supplement. Retrieved from https://www.nafsa.org/_/File/_/marapr10_criticall y_speaking.pdf

Brown, H. D. (2001). Teaching by principles: An interactive approach to language pedagogy (2nd ed.). Longman.

Buranapatana, M. (2006). Enhancing critical thinking of undergraduate thai students through dialogic inquiry. Retrieved from http://www.canberra.edu.au/researchrepository/fi le/dd8c1ad7-b3e4-3d00-6ec9ff463dd926c6/1/full text.pdf

Changwong, K., Sukkamart, A., \& Sisan, B. (2018). Critical thinking skill development: Analysis of a new learning management model for Thai high schools. Journal of International Studies, 11(2), 37-48. doi:10.14254/2071-8330.2018/11-2/3

Hughes, J. (2014). Critical Thinking in the language classroom. ELI.

Hughes, W., \& Lavery, J. (2008). Critical thinking: An introduction to the basic skills (5th ed.). Broadview Press.

Husna, N. (2019). Developing students' critical thinking through an integrated extensive reading program. TEFLIN Journal, 30(2), 212-230. http://dx.doi.org/10.15639/teflinjournal.v30i2/212 $-230$

Junining, E. (2016). Developing critical thinking skills in language teaching: Oral interpretation class. Prosiding Ictte Fkip Uns 2015, 1(1), 870-873.

Kelley, D. (2014). The art of reasoning: An introduction to logic and critical thinking. W. W. Norton \& Company, Inc.

Lai, E. R. (2011). Critical thinking: A literature review. Pearson.

Lau, J. Y. F. (2011). An intoduction to critical thinking and creativity: Think more, think better. John 
Wiley \& Sons, Inc.

Marin, L. M., \& Halpern, D. F. (2010). Pedagogy for developing critical thinking in adolescents: Explicit instruction produces greatest gains. Thinking Skills and Creativity, 6(2011), 1-13. https://doi.org/10.1016/j.tsc.2010.08.002

Masduqi, H. (2011). Critical thinking skills and meaning in english language teaching. TEFLIN Journal. https://doi.org/10.15639/TEFLINJOURNAL.V22I 2/185-200

McKinley, J. (2013). Displaying critical thinking in EFL academic writing: A discussion of Japanese to English contrastive rhetoric. RELC Journal. 44(2), https://doi.org/10.1177/0033688213488386

McMillan, J. H. (1987). Enhancing college students' critical thinking: A review of studies. Research in Higher Education, 26(1), 3-29. https://doi.org/10.1007/bf00991931

Miekley, J. P. (2014). What makes critical thinking critical for adult ESL students. CATESOL Journal, 25(1), 143-150.

Moore, B. N., \& Parker, R. Critical thinking, $9^{\text {th }}$ ed.. McGraw-Hill Higher Education.

Paul, R. (2005). The state of critical thinking today. New Directions for Community Colleges, 2005(130), 27-38. https://doi.org/10.1002/cc.193

Paul, R., \& Elder, L. (2005). A guide for educators to critical thinking competency standards: Standards, principles, performance indicators, and outcomes with a critical thinking master rubric. Foundation for Critical Thinking.

Paul, R., \& Elder, L. (2013). Critical thinking: Intellectual standards essential to reasoning well within every domain of thought. Journal of Developmental Education, 3(36), p34-35.

Pike, G. R. (1996). Assessing the critical thinking abilities of college students. Assessment Update, 8(2), 10-11. https://doi.org/10.1002/au.3650080208

Putri, O. (2014). Investigating junior high school students' critical thinking in reading (Unpublished master's thesis). Universitas Pendidikan Indonesia, Bandung, Indonesia.

Ralston, P. A., \& Bays, C. L. (2015). Critical thinking development in undergraduate engineering students from freshman through senior year: A 3-cohort longitudinal study. American Journal of Engineering Education, 2(6), 85-98. retrieved 20/01/2020 from https://files.eric.ed.gov/fulltext/EJ1083228.pdf

Rezaei, S., Derakhshan, A., \& Bagherkazemi, M. (2011). Critical thinking in language education. Journal of Language Teaching and Research, 2(4), 769-777. https://doi.org/10.4304/jltr.2.4.769-777

Schafersman, S. (1991). An introduction to critical thinking. Retrieved March, 1-13. Retrieved from http://facultycenter.ischool.syr.edu/wpcontent/uploads/2012/02/Critical-Thinking.pdf

Tosuncuoglu, I. (2018). Place of critical thinking in EFL. International Journal of Higher Education, 4(7), 26-32. doi: 10.5430/ijhe.v7n4p26

Uribe-Enciso, O. L., Uribe-Enciso, D. S., \& del Pilar Vargas-Daza, M. (2017). Critical thinking and its importance in education: Some reflections. Rastros Rostros, 34(19), 78-88. doi:https://doi.org/10.16925/ra.v19i34.2144

Vdovina, E. (2013). Developing critical thinking in the english language classroom: A lesson plan. ELTA Journal, 1(1), 54-68. retrieved 20/01/2020 from http://eltajournal.org.rs/wpcontent/uploads/2013/12/VII-Developing-CriticalThinking-in-the-English-Language-classroom.pdf

Vujic, B. N., \& Jerkovic, M. (2014). Improving reading and speaking skills through critical thinking. ELTA Newsletter.

Wood, R. (2002). Critical thinking. retrieved 20/06/2019 from https://www.robinwood.com/Democracy/General Essays/CriticalThinking.pdf

Zheng, J. (2014). A study of senior students' critical reading competence via analyzing their reading reports. International Journal of Learning, Teaching and Educational Research, 1(8), 215221. 